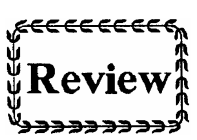

\title{
A review of earthquake occurrences and observations in Nigeria*
}

\author{
Ofonime Umo Akpan ${ }^{\star}$ and Tahir Abubakar Yakubu \\ Centre for Geodesy and Geodynamics, Toro 740103, Nigeria
}

\begin{abstract}
Although Nigeria is not located within the major seismic zones of the world; over the years, several minor earthquakes have been experienced in some parts of the country. The first widely reported occurrence of an Earth tremor in Nigeria was in 1933. Other events were reported in 1939, 1964, 1984, 1990, 1994, 1997, 2000 and 2006. The intensities of these events ranged from III to VI based on the Modified Mercalli Intensity Scale. Of these events, only the 1984, 1990, 1994 and 2000 events were instrumentally recorded. They had body wave magnitudes ranging from 4.3 to 4.5 , local magnitudes between 3.7 and 4.2, and surface wave magnitudes of 3.7 to 3.9. When these events occurred, there were no functional seismological observatories in Nigeria. However, that has now changed with the establishment of a seismographic network managed by the Centre for Geodesy and Geodynamics (CGG), Toro, Nigeria. Presently, the network has four operational stations equipped with 24-bit 4-channel recorders and broadband 30-second seismometers. Efforts are being made to establish more stations and migrate to real-time collection of seismic data using the general packet radio service (GPRS) technology as well as automatic location of events. Remote sensing, geological and geophysical studies have revealed the presence of a NNE-SSW trending Ifewara-Zungeru fault zone which has been shown to be linked with the Atlantic fracture system. The dynamics of the Atlantic fracture zones have been suggested to be responsible for the seismic activities experienced in the areas.
\end{abstract}

Key words: Nigeria; seismic activity; seismological observatories; Ifewara-Zungeru fault zone CLC number: P315.5 Document code: A

\section{Introduction}

Nigeria lies on the eastern flank of the Atlantic Ocean, and since Jurassic times, the Atlantic Ocean margins have been opening consistently. Unlike the Pacific Ocean margins which are characterized by subduction tectonics and occurrence of devastating earthquakes, the Atlantic margins are generally thought to be quiet and as a result, there was little consciousness and preparedness for earthquake occurrences and mitigation in Nigeria and west Africa. However, earthquakes have been reported in some countries in the west coast of Africa that border the Atlantic Ocean like Ghana, Ivory Coast and Liberia (Burke, 1969), Sierra Leone and Guinea (Kogbe and Delbos, 1984). Also, some seismic

\footnotetext{
* Received 18 November 2009; accepted in revised form 8 January 2010; published 10 June 2010.

^Corresponding author. e-mail: ofonua@yahoo.com

(C) The Seismological Society of China and Springer-Verlag Berlin Heidelberg 2010
}

events have occurred within the last 70 years especially in the southwestern part of Nigeria, but no destruction and loss of lives were reported and/or documented; they were only felt as vibrations. This is an indication that micro-earthquakes might actually be occurring but the lack of seismic data occasioned by the non-availability of seismological stations had made the determination of the locations and magnitudes of these events difficult. In 2002, the Federal Government of Nigeria established the Centre for Geodesy and Geodynamics in Toro and saddled it with the responsibility of monitoring seismic activities in the country. Since 2006 the centre has been managing the Nigeria National Network of Seismological Stations (NNNSS) established by the National Agency for Science and Engineering Infrastructure (NASENI), Abuja. The NNNSS presently has four operational stations equipped with 24-bit 4-channel recorders (digitizer and data logger) and broadband seismometers (Table 1, Figure 1). 
Table 1 Location of seismic stations established by Centre for Geodesy and Geodynamics, Nigeria

\begin{tabular}{|c|c|c|c|c|}
\hline No. & $\begin{array}{l}\text { Station } \\
\text { code }\end{array}$ & Name & $\begin{array}{l}\text { Geologic } \\
\text { foundation }\end{array}$ & Instrument \\
\hline 1 & OYO & Oyo & Granite & $\begin{array}{l}\text { SP-400 seismometer, DR4000 } \\
\text { recorder }\end{array}$ \\
\hline 2 & IBN & Ibadan & Gneiss & No instrument installed \\
\hline 3 & IFE & Ile-Ife & Gneiss & $\begin{array}{l}\text { EP-105 broadband seismome- } \\
\text { ter, DR } 4000 \text { recorder }\end{array}$ \\
\hline 4 & AWK & Awka & $\begin{array}{l}\text { Shale and } \\
\text { siltstone }\end{array}$ & No instrument installed \\
\hline 5 & NSU & Nsukka & Sandstone & $\begin{array}{l}\text { EP-105 broadband seismome- } \\
\text { ter, DR } 4000 \text { recorder }\end{array}$ \\
\hline 6 & $\mathrm{ABK}$ & Abakiliki & Sandstone & No instrument installed \\
\hline 7 & ABJ & Abuja & Granite & No instrument installed \\
\hline 8 & TOR & Toro (Central) & Gneiss & No instrument installed \\
\hline 9 & KAD & Kaduna & Granite & $\begin{array}{l}\text { EP-105 broadband seismome- } \\
\text { ter, DR } 4000 \text { recorder }\end{array}$ \\
\hline 10 & MNA & Minna & Granite & No instrument installed \\
\hline
\end{tabular}

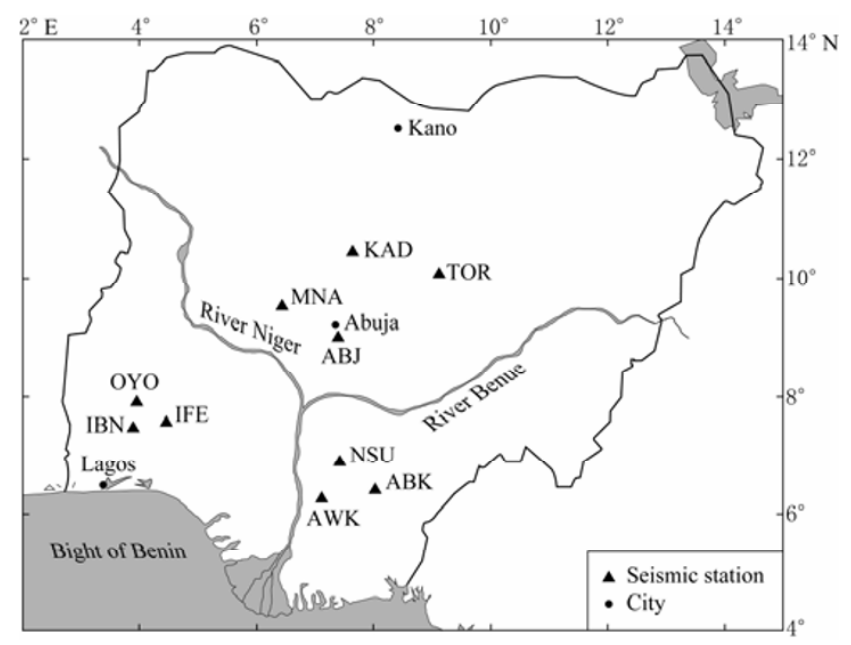

Figure 1 Distribution of seismic stations and their codes (station names are given in Table 1) in Nigeria.

Presented here is a summary of earthquakes that have been instrumentally recorded within Nigeria by agencies outside the country and the probable epicenters, felt areas and intensities of others that were not instrumentally recorded.

\section{Description of some Nigerian earth- quakes}

The history of earthquake occurrences in Nigeria dates back to the 1930's when tremors were reported in some parts of Warri in 1933, and Ibadan on 22nd June 1939 (Ananaba, 1991). The 1939 event was also felt in parts of Ile-Ife and Lagos and was probably related to the Accra earthquake which occurred on the same day (Ajakaiye et al, 1987). Another reported event occurred on 21st December 1963 at about 18:30 Greenwich Mean
Time (GMT) near Ijebu-Ode with an epicentral intensity of about $\mathrm{V}$.

The event that generated much attention and also received wide publicity occurred on Saturday, July 28, 1984 and was felt in Ibadan, Ijebu-Ode, Shagamu and Abeokuta in southwestern Nigeria. This was so due to the fact that these areas lie within the Nigerian basement complex which was hitherto thought to be tectonically stable (Ajakaiye et al, 1987). The tremor was strongly felt by a good number of people in these areas, buildings and trees were shaken, items on shelves fell down and the time of occurrence was given as 12:10 GMT. Adekoya (1984) described two vibrations that accompanied the event in the Ibadan area. The first which was probably a foreshock occurred as a mild vibration that shook the walls of buildings with the clattering of louvers and lasted about ten seconds. The second which was the main shock happened about five minutes later and was more violent as buildings were shaken with their floors undulating contemporaneously. Ajakaiye et al (1987) added that two more aftershocks were felt in quick succession, bringing the total number of shocks to four within a period of twenty minutes. A maximum epicentral intensity (Modified Mercalli Scale) of VI was assigned to this event on the basis of information compiled on the macroseismic effects. Seismological observatories at Zaria, Nigeria and Lamto, Cote d'Ivoire recorded this event and the epicenter was located close to Ijebu-Ode (Ajakaiye et al, 1987; Onuoha, 1989; Figure 2). According to Ajakaiye et al (1987) the Zaria station recorded a very weak P-wave onset and a clear S-wave arrival at about 12:14

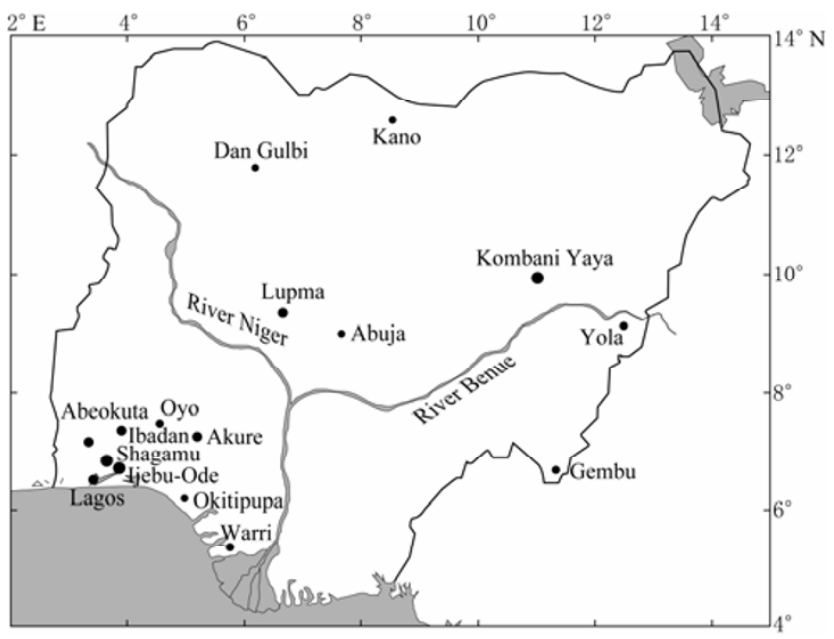

Figure 2 Map of Nigeria showing the areas where some events were felt (Diameter of the solid dot denotes intensity of the events given in Table 5). 
GMT, but the $\mathrm{P}$ and $\mathrm{S}$ waves were clearly recorded at all the four vertical components of the Lamto seismic array. Onuoha (1989) and Ojo (1995) reported the occurrence of another event which was another aftershock of the July 28, 1984 event at about 10:20 GMT on Thursday, August 2, 1984 and the vibration was felt within the same area. The tremor lasted less than one minute, and the noise which accompanied it was loudest at Ijebu-Ode, Ijebu-Remo and Shagamu where houses were shaken, hanging objects rattled with some falling down, lower at Abeokuta and faint at Ibadan and Oyo where the effect was mild. This event was given an epicentral intensity of V (Onuoha, 1989).

Between 21:00 GMT on 18 June to 2:00 GMT 19 June 1985, a possible earthquake occurred at Kombani Yaya, a rural settlement in northern Nigeria (Ugodulunwa et al, 1986; Ajakaiye et al, 1988). Two surface fractures $1.0 \mathrm{~km}$ and $1.5 \mathrm{~km}$ long, $0.2 \mathrm{~m}$ wide and $2 \mathrm{~m}$ deep at right angles to each other were observed at the epicenter of the event (Ajakaiye et al, 1988). The accompanying vibration was given an intensity level of $\mathrm{V}$ on the Modified Mercalli Scale.
Another event that attracted much attention occurred on Wednesday, June 27, 1990 and was felt around Ibadan and environs (Ananaba, 1991; Ojo, 1995; Osagie, 2008). This was recorded by the seismic station of Geological Survey of Nigeria in Ilorin and had a local magnitude of 3.7. Although the epicenter was not given, it could be inferred that it was close to that of Ijebu-Ode event. Osagie (2008) stated that residents of Oluyole Estate Extensions, Apata, Odoowa and Felele areas of Ibadan experienced the highest shaking, which lasted less than 10 seconds. He mentioned that there were violent vibrations of building foundations, braking of louver blades of windows, sopping clocks, washing basins and plates tumbled, spilling their contents. The tremor sent people into the streets, though no one was killed. An earth tremor occurred on November 7, 1994 in Dan Gulbi near Gusau (Northern Nigeria). Three stations in Cote d'Ivoire recorded this event. The origin time was calculated to be 05:07:51.00 GMT, and the local magnitude was 4.2 (Table 2). However, no vibration or damage was reported. The stations used in locating the event are given in Table 4.

Table 2 Location parameters of the November 7, 1994 earth tremor (after ISC, 2001)

\begin{tabular}{ccccccr}
\hline \multicolumn{2}{c}{ Origin time (GMT) } & $\begin{array}{c}\text { Lat. } \\
/{ }^{\circ} \mathrm{N}\end{array}$ & $\begin{array}{c}\text { Long. } \\
/{ }^{\circ} \mathrm{E}\end{array}$ & $\begin{array}{c}\text { Focal depth } \\
/ \mathrm{km}\end{array}$ & $\begin{array}{c}\text { Number of } \\
\text { stations }\end{array}$ & $M_{\mathrm{L}}$ \\
\hline a-mo-d & h:min:s & & Agency & 3 & Lamto, Cote d'Ivoire \\
\hline $1994-11-07$ & $05: 07: 51.00$ & 11.650 & 6.350 & 30.0 & 3.2 & 3 \\
\hline
\end{tabular}

On Tuesday, March 7, 2000 another earthquake occurred and was felt within Ibadan and environs. Elueze (2003) reported that the shock lasted about $10 \mathrm{sec}-$ onds and was felt between 15:30 to 16:00 GMT. No visible damage, failure or collapse of structures and casualty were reported or substantiated throughout the area The event was merely felt as ground vibration. He further stated that the quake was mostly experienced in high-rise buildings and houses within the more developed city centre, but apparently unnoticed in the less built up plains that have considerable overburden and uninformed dwellers. The vibrations were also felt in Ijebu-Ode, Shagamu, Abeokuta, Oyo and Akure in southwestern Nigeria. The event was recorded and located by four international organizations, the National Earthquake Information Centre (NEIC) of the United States Geological Survey (USGS), the International Data Centre (IDC), Vienna, Austria, the International Seismological Centre (ISC), United Kingdom and Engadhl, van der Hilst and Buland (EHB). These organizations obtained approximately same origin times and magnitudes for the event (Table 3). The phase data for this event was converted to SEISAN format using program NORIMS (Ottemoller et al, 2009) and the event was relocated using the program HYPOCENTER 3.2 (Lienert and Havskov, 1995). The origin time and body wave magnitude calculated using SEISAN are given in the last column of Table 3 . All these agencies located the epicenter somewhere near Okitipupa which is about 184 $\mathrm{km}$ east of Lagos. The stations used in locating this event are given in Table 4.

On Sunday, May 7, 2000, another Earth tremor was reported in Akure (Odeyemi, 2006). The shock took place at about 11:00 GMT, and lasted about 10 seconds. He reported that the ground was shaken to the extent that flower vases and wall-mounted photographs fell off. However, no damages were recorded in buildings (Personal communication with Dr. Anifowose A. Y. B.). Furthermore, people who were indoors mostly felt the shock. The epicentral intensity of this event was IV. At about 11:20 GMT on 25th March, 2006, a suspected earth tremor was reported in a rural settlement of Lupma 
near Minna, northern Nigeria. Some people who were working in their farms had to run for safety. Eye-witness accounts have it that sudden vibration was felt around the area and sound like that of a moving train was heard. There were cracks in buildings, pictures on walls of houses fell to the ground and rock outcrops within the

Table 3 Location parameters of the March 7, 2000 earthquake (modified after ISC, 2009)

\begin{tabular}{|c|c|c|c|c|c|c|c|c|c|}
\hline \multicolumn{2}{|c|}{ Origin time (GMT) } & \multirow{2}{*}{ RMS } & \multirow{2}{*}{$\begin{array}{l}\text { Lat. } \\
{ }^{\circ} \mathrm{N}\end{array}$} & \multirow{2}{*}{$\begin{array}{l}\text { Long. } \\
/^{\circ} \mathrm{E}\end{array}$} & \multirow{2}{*}{$\begin{array}{l}\text { Depth } \\
\text { /km }\end{array}$} & \multirow{2}{*}{$\begin{array}{l}\text { Number of } \\
\text { stations }\end{array}$} & \multirow{2}{*}{$m_{\mathrm{b}}$} & \multirow{2}{*}{$M_{\mathrm{S}}$} & \multirow{2}{*}{ Agency } \\
\hline a-mo-d & h:min:s & & & & & & & & \\
\hline 2000-03-07 & $15: 53: 24.03$ & 1.38 & 6.224 & 5.147 & 10.0 & 18 & 4.5 & & NEIC \\
\hline 2000-03-07 & $15: 53: 24.45$ & 1.13 & 6.235 & 4.950 & 0 & 15 & 4.3 & 3.7 & IDC \\
\hline 2000-03-07 & $15: 53: 24.49$ & 1.04 & 6.290 & 5.070 & 10.0 & 27 & 4.4 & 3.9 & ISC \\
\hline 2000-03-07 & $15: 53: 25.10$ & 0.80 & 6.253 & 5.036 & 5.3 & 25 & & & EHB \\
\hline 2000-03-07 & $15: 53: 26.20$ & 0.40 & 6.359 & 5.068 & 10.0 & 24 & 4.3 & & $\mathrm{CGG}$ \\
\hline
\end{tabular}

Note: NEIC is National Earthquake Information Centre, IDC is International Data Centre, ISC is International Seismological Centre, EHB is Engadhl, van der Hilst and Buland, CGG is Centre for Geodesy and Geodynamics.

Table 4 List of stations used in determining the epicenters of the November 7, 1994 and March 7, 2000 earthquakes (after ISC, 2009)

\begin{tabular}{|c|c|c|c|c|c|c|c|}
\hline No. & $\begin{array}{l}\text { Station } \\
\text { code }\end{array}$ & Name & Region & No. & $\begin{array}{l}\text { Station } \\
\text { code }\end{array}$ & Name & Region \\
\hline 1 & BGCA & Bogoin & Central African Republic & 15 & SCHQ & Schefferville & Quebec, Canada \\
\hline 2 & ESDC & $\begin{array}{l}\text { Sonseca array beam reference } \\
\text { point }\end{array}$ & Spain & $\begin{array}{l}16 \\
17\end{array}$ & $\begin{array}{l}\text { HARN } \\
\text { LPAZ }\end{array}$ & $\begin{array}{l}\text { Harre } \\
\text { La Paz }\end{array}$ & $\begin{array}{l}\text { Nepal } \\
\text { Bolivia }\end{array}$ \\
\hline 3 & BOSA & Boshof & South Africa & 18 & MEGN & Megha & Nepal \\
\hline 4 & BRAR & $\begin{array}{l}\text { Belbasi array beam reference } \\
\text { point }\end{array}$ & Turkey & $\begin{array}{l}19 \\
20\end{array}$ & $\begin{array}{l}\text { KOLN } \\
\text { DANN }\end{array}$ & $\begin{array}{l}\text { Koldanda } \\
\text { Dangsing }\end{array}$ & $\begin{array}{l}\text { Nepal } \\
\text { Nepal }\end{array}$ \\
\hline 5 & GERES & $\begin{array}{l}\text { GERESS array beam reference } \\
\text { point }\end{array}$ & Bayern, Germany & $\begin{array}{l}21 \\
22\end{array}$ & $\begin{array}{l}\text { KKN } \\
\text { GUN }\end{array}$ & $\begin{array}{l}\text { Kakani } \\
\text { Gumba }\end{array}$ & $\begin{array}{l}\text { Nepal } \\
\text { Nepal }\end{array}$ \\
\hline 6 & $\mathrm{KHC}$ & Kasperske Hory & Czech Republic & 23 & PLCA & Paso Flores & Rio Negro, Argentina \\
\hline $\begin{array}{l}7 \\
8\end{array}$ & $\begin{array}{l}\text { EKA } \\
\text { NOA }\end{array}$ & $\begin{array}{l}\text { Eskdalemuir array } \\
\text { NORSAR array beam refer- }\end{array}$ & $\begin{array}{l}\text { Scotland, United Kingdom } \\
\text { Norway }\end{array}$ & 24 & CMAR & $\begin{array}{l}\text { Chigan Mia array beam } \\
\text { reference point }\end{array}$ & Thailand \\
\hline 9 & FINES & $\begin{array}{l}\text { ence point } \\
\text { FINESS array beam reference } \\
\text { point }\end{array}$ & Finland & $\begin{array}{l}25 \\
26\end{array}$ & $\begin{array}{l}\text { ULM } \\
\text { YKA }\end{array}$ & $\begin{array}{l}\text { Lac du Bonnet } \\
\text { Yellow Knife array beam } \\
\text { reference point }\end{array}$ & $\begin{array}{l}\text { Manitoba, Canada } \\
\text { Northwest territories, Canada }\end{array}$ \\
\hline $\begin{array}{l}10 \\
11\end{array}$ & $\begin{array}{c}\text { KAF } \\
\text { ARCES }\end{array}$ & $\begin{array}{l}\text { Kangasniemi } \\
\text { ARCESS array beam reference }\end{array}$ & $\begin{array}{l}\text { Finland } \\
\text { Norway }\end{array}$ & 27 & ASAR & $\begin{array}{l}\text { Alice Springs array beam } \\
\text { reference point }\end{array}$ & Northern territory, Australia \\
\hline & & point & & 28 & LIC & Lamto & Cote d'Ivoire \\
\hline 12 & CPUP & Villa Florid & Paraguay & 29 & $\mathrm{KIC}$ & Kosan Boka & Cote d'Ivoire \\
\hline 13 & HYB & Hyderabod & Andhra Pradesh, India & 30 & $\mathrm{TIC}$ & Toumodi & Cote d'Ivoire \\
\hline 14 & GHAN & Ghanteswor & Nepal & & & & \\
\hline
\end{tabular}

Table 5 List of historical Earth tremors in Nigeria

\begin{tabular}{|c|c|c|c|c|c|}
\hline \multicolumn{2}{|c|}{ Origin time (GMT) } & \multirow{2}{*}{ Felt areas } & \multirow{2}{*}{ Intensity } & \multirow{2}{*}{ Magnitude } & \multirow{2}{*}{ Probable epicenter } \\
\hline a-mo-d & h:min:s & & & & \\
\hline 1933 & & Warri & & & \\
\hline $1939-06-22$ & $19: 19: 26$ & Lagos, Ibadan, Ile-Ife & & $6.5\left(M_{\mathrm{L}}\right), 5.3\left(M_{\mathrm{S}}\right)$ & Akwapim fault in Ghana \\
\hline $1963-12-21$ & $18: 30$ & Ijebu-Ode & $\mathrm{V}$ & & Close to Ijebu-Ode \\
\hline $1982-10-16$ & & Jalingo, Gembu & III & & Close to Cameroun volcanic line \\
\hline 1984-07-28 & $12: 10$ & Ijebu-Ode, Ibadan, Shagamu, Abeokuta & VI & & Close to Ijebu-Ode \\
\hline 1984-08-02 & 10:20 & $\begin{array}{l}\text { Ijebu-Ode, Ijebu-Remo, Ibadan, Oyo, } \\
\text { Shagamu, Abeokuta }\end{array}$ & $\mathrm{V}$ & & Close to Ijebu-Ode \\
\hline 1984-12-08 & & Yola & & & Close to Cameroun volcanic line \\
\hline 1985-06-18 & 21:00 & Kombani Yaya & IV & & Kombani Yaya \\
\hline 1990-06-27 & & Ibadan & & $3.7\left(M_{\mathrm{L}}\right)$ & Close to Ijebu-Ode \\
\hline 1994-11-07 & $05: 07: 51$ & & & $4.2\left(M_{\mathrm{L}}\right)$ & Dan Gulbi \\
\hline 1997 & & Okitipupa & IV & & Close to Okitipupa \\
\hline 2000-03-07 & $15: 53: 54$ & Ibadan, Akure, Abeokuta, Ijebu-Ode, Oyo & & $4.5\left(m_{\mathrm{b}}\right), 3.9\left(M_{\mathrm{S}}\right)$ & Close to Okitipupa \\
\hline 2000-05-07 & 11:00 & Akure & IV & & Close to Okitipupa \\
\hline $2005-03$ & & Yola & III & & Close to Cameroun volcanic line \\
\hline 2006-03-25 & $11: 20$ & Lupma & III & & \\
\hline
\end{tabular}


immediate vicinity of the vibration were seriously shattered. There was an aftershock after about ten seconds. A maximum epicentral intensity of IV was assigned to the event. A comprehensive list of all historical earthquakes in Nigeria is given in Table 5.

\section{Discussion}

The seismic events of 21 December 1963, 28 July 1984, 27 June 1990 and 7 March, 2000 had similar intensities and were felt within the same areas in southwestern Nigeria (Figures 2 and 3; Elueze, 2003). The mechanism of these seismic activities can be understood by looking at the Precambrian fractures and its extension into Atlantic Ocean. Elsewhere, Francheteau and Le Pichon (1972) had identified the link between the tremor-prone Akwapim fault around Accra, Ghana, with the Romanche fracture zone, while the Ivory Coast fracture zone which projects onto the Ivory Coast basement is considered to be related to the seismic activities around Abidjan (Burke, 1969). Similarly, seismic activities around Kribi in Cameroun are considered to take place along the landward continuation of the Ascension fracture zone (Burke, 1969). In Sierra Leone, there is also a collinear relationship between the trends of basement faults and the Atlantic fracture zones. Kogbe and Delbos (1984) showed that the devastating earthquake which occurred in Guinea on 23rd December, 1983, took place along the suture zone between the West African craton and adjacent upper Proterozoic metasediments which represents the landward extension of the Guinea fracture zone.

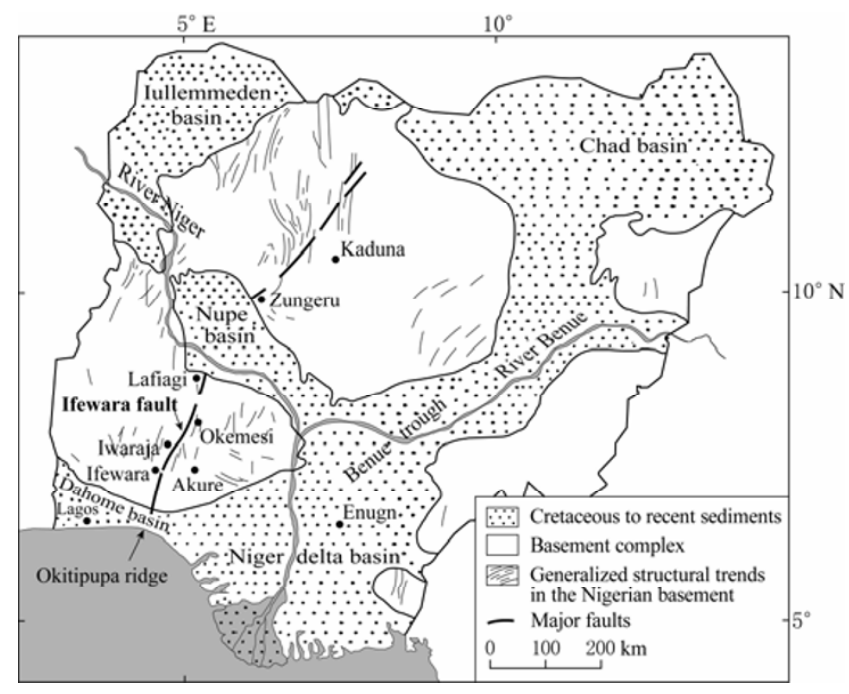

Figure 3 Geological map of Nigeria showing the IfewaraZungeru fault (modified after Odeyemi, 2006).
Since Nigeria lies on the same flank of the Atlantic Ocean as the countries mentioned earlier, similar features are expected. The presence of fracture zones which prominently traverse the western half of Nigeria had been pointed out by Ajakaiye et al (1987), Odeyemi (1989) and Elueze (1990). This megastructure named Ifewara-Zungeru fault is the longest linear feature within the Precambrian basement complex of Nigeria, and stretches from just east of Ijebu-Ode in the south, through Ifewara, Iwaraja and Okemesi, to the basin of river Niger, south of Lafiagi to Zungeru and beyond to Kalangai in northwestern Nigeria (Anifowose et al, 2006; Figure 3). The reported occurrence of an earth tremor in Lupma which lies along the northward extension of this fault zone also supports the existence of this fault zone. The epicenter of the 1994 tremor also lies along the northern extension of this fault zone. Recent studies (Adepelumi et al, 2008; Anifowose et al, 2010) on the southern part of the fault zone using integrated remote sensing and geophysical techniques described the characteristics of this NNE-SSW fracture zone. The extension of this fault southwards under the Cretaceous to Recent sediments of the Dahomey basin into the Atlantic Ocean as fracture zones had been identified by Wright (1976), Elueze (2003) and Odeyemi (2006). The epicenters of these earthquakes lie between the Romanche and Chain fracture zones. Seismic activities in these areas could have resulted from movements of the Oceanic fracture system (Elueze, 2003; Anifowose et al, 2006).

The occurrences of Earth tremors in Yola and Gembu areas in the northeastern part of the country might be related to seismic activities that occurred around the Cameroun mountains due to their proximity to the Cameroun mountains. The 1985 event in Kombani Yaya could be attributed to the strike-slip Kaltungo faults (Ugodulunwa et al, 1986).

\section{Conclusion}

For years, Nigeria was thought to be aseismic and this development made Nigerian geoscientists develop a lackadaisical attitude towards research into the occurrences of earthquakes in the country, hence, very little has been done before the 1984 event. The seismic events 28th July 1984, 27th June 1990 and 7th March 2000 within the southwestern part of the country aroused the consciousness of Nigerian geoscientists to the fact that the country might not be tectonically stable as earlier thought. However, within the past few decades, Nigeria 
had experienced earth tremors with intensity levels ranging from IV to VI. The ones that were instrumentally recorded had magnitudes varying from 3.7 to 4.5 . Remote sensing, geological and geophysical evidences have revealed the presence of deep-seated NNE-SSW lineaments (the Ifewara-Zungeru fault) which transcend the western half of the country. These Precambrian fractures are thought to be linked with some transform fracture zones in the Atlantic Ocean. Some scholars have suggested that the possible triggering mechanism of the Nigerian earth tremors might be associated with these fracture zones.

The Centre for Geodesy and Geodynamics, Toro has been managing the Nigeria National Network of Seismographic Stations (NNNSS) since 2006. Presently, seismic equipment has been successfully installed at four stations located in Kaduna, Nsukka, Oyo and Ile-Ife. Plans are underway to install equipment in the other stations and migrate to real-time collection of data using the GPRS technology in the next few years. With the efforts made so far, the various governments of Nigeria and indeed all Nigerians would be adequately informed of the occurrence of a devastating earthquake in the country.

\section{References}

Adekoya J A (1984). Earthquakes in Nigeria. Sunday Sketch Newspaper, August $26,13$.

Adepelumi A A, Ako B D, Ajayi T R, Olorunfemi A O, Awoyemi M O and Falebita D E (2008). Integrated geophysical studies of the Ifewara transcurrent fault system, Nigeria. J Afr Earth Sci 52: 161-166.

Ajakaiye D E, Daniyan M A, Ojo S B and Onuoha K M (1987). The July 28, 1984 southwestern Nigeria earthquake and its implications for the understanding of the tectonic structure of Nigeria. In: Wassef A M, Boud A and Vyskocil P. Recent Crustal Movements in Africa. Journal of Geodynamics 7: 205-214.

Ajakaiye D E, Olatinwo M D and Scheidegger A E (1988). Another possible earthquake near Gombe in Nigeria on the 18-19 June 1985. Bull Seism Soc Amer 78(2): 1 006-1 010.

Ananaba S E (1991). Dam sites and crustal megalineaments in Nigeria. ITC Journal 1: 26-29.

Anifowose A Y B, Odeyemi I B and Borode A M (2006). The tectonic significance of the Ifewara-Zungeru megastructure in Nigeria. In: Teme S C and Ezeigbo C U. Proceedings of the 1st International Workshop on Geodesy and Geodynamics. Centre for Geodesy and Geodynamics, Toro, Nigeria, $17-28$.
Anifowose A Y B, Oladapo M I, Akpan O U, Ologun C O, Adeoye-Oladapo O O, Tsebeje S Y and Yakubu T A (2010). Systematic multi-technique mapping of the southern flank of Iwaraja fault, Nigeria. Jour of Applied Science and Technology 15(1-2): 70-76.

Burke K (1969). Seismic areas of the Guinea coast where Atlantic fracture zones reach Africa. Nature 222(5194): 655-657.

Elueze A A (1990). Geological setting of Proterozoic schist belts and relationship to crustal movement. In: Ofoegbu C O, Osemekhain J E A, Ekwelibe P, Ezeife N, Ejezie S and Obiaga T I. Proceedings of the 5th International Seminar and Exhibition on Earthquake Prognostics. National Technical Committee on Earthquake Phenomena, Lagos, Nigeria, 108-114.

Elueze A A (2003). Evaluation of the 7 March 2000 earth tremor in Ibadan area, southwestern Nigeria. Jour Min Geol 39(2): 79-83.

Francheteau J and Le Pichon X (1972). Marginal fracture zones as structural framework of continental margins in the South Atlantic Ocean. J Geophys Res 56: 991-1 007.

International Seismological Centre (ISC) (2009). Rectangular selection. 2009-09-12, http://www.isc.ac.uk/search/bulletin/rectang.html.

Kogbe C A and Delbos L (1984). The recent Guinea earthquake: Probable origin and geographic implications. Pangea 2: 17-19.

Lienert B R E and Havskov J (1995). A computer program for locating earthquakes both locally and globally. Seis Res Lett 66: 26-36.

Odeyemi I B (1989). Precambrian crustal fractures as possible sites of seismic activity in Nigeria: Ifewara fault as a case example. In: Ajakaiye D E, Ojo S B, Daniyan M A and Abatan A O. Proceedings of the National Seminar on Earthquakes in Nigeria. National Technical Committee on Earthquake Phenomena, Lagos, Nigeria, 225.

Odeyemi I B (2006). The Ifewara fault in southwestern Nigeria: Its relationship with fracture zones along the Nigerian coast. Centre for Geodesy and Geodynamics, Toro, Bauchi State, 1-13.

Ojo O M (1995). Survey of occurrences in Nigeria of natural and man-made hazards related to geological processes. In: Onuoha K M and Offodile M E. Proceedings of the International Workshop on Natural and Man-made Hazards in Africa. Nigerian Mining and Geosciences Society, Jos, Nigeria, $10-14$.

Onuoha K M (1989). Historical perspectives of earthquakes in West Africa. In: Ajakaiye D E, Ojo S B, Daniyan M A and Abatan A O. Proceedings of the National Seminar on Earthquakes in Nigeria. National Technical Committee on Earthquake Phenomena, Lagos, Nigeria, 129-141.

Osagie E O (2008). Seismic activity in Nigeria. The Pac Jour Sci and Tech 9(2): $1-6$.

Ottemoller L, Voss P and Havskov J (2009). SEISAN: The Earthquake Analysis Software for Windows, Solaris, Linux and Macosx (version 8.2.1). 2009-10-11, http://seis.geus.net/software/seisan/seisan.pdf.

Ugodulunwa F X O, Ajakaiye D E, Guiraud M and Hossan M T (1986). The Pindiga and Obi fractures - Possible earthquake sites in Nigeria. In: Proceedings of the 3rd International Conference on Current Research in Geophysics and Geophysical Research in Africa. Faculty of Natural Sciences, University of Jos, Jos, Nigeria, 6.

Wright J B (1976). Fracture systems in Nigeria and initiation of fracture zones in the South Atlantic. Tectonophysics 34: 43-47. 